Rafae Michalowski ${ }^{1}$

\title{
Przetarg ograniczony przy sprzedaży gruntów z Zasobu Własności Rolnej Skarbu Państwa a wsparcie gospodarstw rodzinnych (wybrane zagadnienia)
}

W regulacji ustawy o gospodarowaniu nieruchomościami rolnymi Skarbu Państwa ${ }^{2}$ określenie gospodarstwa rodzinnego pojawiło się w 1994 r. ${ }^{3}$ Wówczas to zmodyfikowano zawarty w jej art. 6 katalog zadań Agencji Własności Rolnej Skarbu Państwa w ten sposób, że pkt 5 tego przepisu wskazywał, że jednym z nich jest tworzenie gospodarstw rolnych, a zwłaszcza powiększanie już istniejących gospodarstw rodzinnych. Poza tym jednak próżno było szukać w treści ustawy jakichkolwiek innych przepisów zawierających to pojęcie. Innymi słowy, brak było konkretnych rozwiązań rzeczywiście służących wspieraniu właśnie tej kategorii jednostek produkcyjnych w rolnictwie. W piśmiennictwie, omawiając wskazaną modyfikację treści art. 6 pkt 5 u.g.n.r. wyrażono opinię, że w ten sposób ustawodawca antycypował przyszłą merytoryczną regulację dotyczącą wspierania gospodarki rodzinnej w rolnictwie. ${ }^{4}$ Trudno jednak akceptować tego rodzaju twórczość legislacyjną. Wszak ewidentne jest, że zmieniając katalog zadań Agencji jednocześnie wprowadzone do ustawy powinny być konkretne rozwiązania mające na celu wsparcie gospodarstw rodzinnych. Bez takowych, art. 6 pkt 5 ustawy pozostawał czczą deklaracją, pozbawioną realnego znaczenia normatywnego. Nietrudno też zauważyć kardynalną niedoskonałość w sformułowaniu omawianego przepisu: wynikało z niego, że powiększanie gospodarstw rodzinnych jest szczególnym przypadkiem tworzenia gospodarstw rolnych - innymi słowy powiększanie już istniejących gospodarstw jest jednocześnie przejawem ich tworzenia, a więc - powstawania nowych. Ten ewidentny lapsus logiczny został skorygowany dopiero w 1999 r. $^{5}$

\footnotetext{
Uniwersytet w Białymstoku.

Ustawa z dnia 19 października 1991 r. o gospodarowaniu nieruchomościami rolnymi Skarbu Państwa, Dz.U. z 2012 r., poz. 1187 z późn. zm., w dalszej części artykułu przywoływana jako u.g.n.r.

3 Zob. art. 1 pkt 5 ustawy z dnia 29 grudnia 1993 r. o zmianie ustawy o gospodarowaniu nieruchomościami rolnymi Skarbu Państwa oraz o zmianie niektórych ustaw, Dz.U. z 1994 r. Nr 1, poz. 3.

4 A. Kołodziej, J. Marczak, Nowelizacja ustawy o gospodarowaniu nieruchomościami rolnymi Skarbu Państwa, „Agroprzemiany” 1994, nr 2-3, wkładka, s. 4-5.

$5 \quad$ Zob. art. 1 pkt 2 lit. a ustawy z dnia 6 maja 1999 r. o zmianie ustawy o gospodarowaniu nieruchomościami rolnymi Skarbu Państwa oraz o zmianie niektórych ustaw, Dz.U. Nr 49, poz. 484.
} 
Jak już wskazywano w doktrynie, swego rodzaju zalążkiem prawnej regulacji wspierania gospodarstw rodzinnych w u.g.n.r. wkomponowanej w regulację przetargowego zbycia gruntów Zasobu stanowiło wprowadzone w 1999 r. uregulowanie przetargu ograniczonego - można było twierdzić, że w większości przypadków tworzone czy też powiększane gospodarstwa przez osoby nabywające grunty w tym trybie mogły być traktowane jako rodzinne. ${ }^{6}$ Trzeba jednak mieć na uwadze, że nie mieliśmy tam do czynienia ściśle rzecz ujmując z regulacją mającą na celu kształtowanie czy wspieranie gospodarki rodzinnej w rolnictwie, której sposób rozumienia byłby w jakiś sposób wyznaczony normatywnie (w związku z tym, że przepis ów nie zawierał pojęcia „gospodarstwo rodzinne” ani w inny sposób nie odwoływał się do wyznaczonego normatywnie sposobu jego rozumienia.

Dopiero w 2003 roku, ustawodawca wprowadził do u.g.n.r., rozwiązania, których osią było pojęcie gospodarstwa rodzinnego. ${ }^{7}$ Dotyczy to zwłaszcza regulacji przetargu ograniczonego. Katalog podmiotów, które mogły być jego uczestnikami wprowadzony został $\mathrm{w}$ treści art. 29 ust. 3b. Najważniejszą kategorią z nich byli oczywiście rolnicy powiększający gospodarstwa rodzinne. Katalog ten został zmodyfikowany w związku z uchwaleniem ustawy z dnia 16 września 2011 r. o zmianie ustawy o gospodarowaniu nieruchomościami rolnymi Skarbu Państwa oraz o zmianie niektórych innych ustaw ${ }^{8}$

Przetarg jest podstawowym w konstrukcji u.g.n.r. trybem sprzedaży gruntów Zasobu. Jednak mając na uwadze faktyczne znaczenie poszczególnych sposobów sprzedaży gruntów ZWRSP mierzone wielkością sprzedanego przy ich wykorzystaniu areału nieruchomości, nietrudno spostrzec, że ich największa część zbywana jest jednak w trybie pozaprzetargowym, osobom uprzywilejowanym pierwszeństwem w nabyciu nieruchomości. Dla przykładu, w 2013 r. w drodze pierwszeństwa sprzedano prawie 93 tys. ha gruntów w ramach ogólem sprzedanych 147,7 tys. ha gruntów ZWRSP. ${ }^{9}$ Stąd celowe jest rozważenie, czy pierwszeństwo może być traktowane jako normatywny środek wspierania gospodarki rodzinnej w rolnictwie uzupełniający regulację przetargu ograniczonego w tym zakresie. Otóż analiza art. 29 u.g.n.r. prowadzi do przeczącej odpowiedzi na tak zadane pytanie. Nie można, mając na uwadze ukształtowanie tej instytucji w u.g.n.r., traktować pierwszeństwa w nabyciu nieruchomości jako instrumentu intencjonalnie ukształtowanego przez prawodawcę do wsparcia gospodarstw rodzinnych. Pełni ono, w zależności od tego, do której kategorii podmiotów uprzywilejowanych pierwszeństwem go odnosimy,

Zob. D. Łobos-Kotowska, Ochrona gospodarstwa rodzinnego w procesie zbywania nieruchomości rolnych przez Agnecję Nieruchomości Rolnych, [w:] Własność i jej ograniczenia w prawie polskim, K. Skotnicki, K. Winiarski (red.), Częstochowa 2004, s. 127 i n.

$7 \quad$ Na mocy art. 12 pkt 11 ustawy z dnia 11 kwietnia 2003 r. o kształtowaniu ustroju rolnego (Dz.U. Nr 64, poz. 592; tekst jednolity Dz.U z 2012 r. poz. 803 z późn. zm).

$8 \quad$ Dz.U. z 2011 r. Nr 233, poz. 1382.

9 Dane dotyczące sprzedaży gruntów z ZWRSP przytaczam za treścią Raportu ANR z działalności na Zasobie Własności Rolnej Skarbu Państwa w 2013 r., Warszawa 2014, dostępnym na stronie: www.bip.anr.gov.pl, s. 6. 
różne funkcje, w tym funkcje quasi-reprywatyzacyjne, ale nie jest wprost powiązana $\mathrm{z}$ funkcją produkcyjną w rolnictwie ani tym bardziej z gospodarką rodzinną. Rozważając aspekt wsparcia gospodarstw rolnych w ramach instytucji pierwszeństwa, prima facie interesująca może być kategoria uprzywilejowanych wskazana $\mathrm{w}$ art. 29 ust. 1a pkt 3 u.g.n.r., czyli dzierżawcy, których umowy dzierżawy trwały faktycznie co najmniej 3 lata. Stanowią oni zresztą grupę, która w największym stopniu korzysta z przywileju nabycia własności gruntu z pominięciem procedury przetargowej, gdyż w 2013 r. na ich rzecz sprzedano ponad 88 tys. ha gruntów. ${ }^{10}$ Jednak uregulowanie pierwszeństwa dzierżawców nie jest w jakikolwiek sposób skojarzone normatywnie $\mathrm{z}$ funkcją wspierania rolnictwa, w tym gospodarki rodzinnej w rolnictwie (co nie zmienia faktu, że rolnicy dzierżawiący grunty Zasobu często korzystają z pierwszeństwa). Przede wszystkim ta kategoria uprzywilejowanych w treści art. 29 ust. 1 pkt 2 u.g.n.r. jest ujęta niezwykle szeroko - nie formułuje się tu jakichkolwiek kwalifikowanych wymogów podmiotowych. Innymi słowy, może to być jakikolwiek podmiot (a nie tylko osoba fizyczna spełniająca kryteria wymagane od rolnika indywidualnego czy też posiadająca same tylko kwalifikacje rolnicze), byleby umowa dzierżawy trwała przez wymagany ustawowo okres - co nie jest wszak bezpośrednio powiązane $\mathrm{z}$ gospodarką rodzinną $\mathrm{w}$ rolnictwie $-\mathrm{z}$ uwzględnieniem art. 28a u.g.n.r. ${ }^{11}$ Nie ma też wymogu, aby dzierżawiona przez uprzywilejowanego pierwszeństwem nieruchomość miała charakter rolny. Jednak, co trzeba zauważyć, w treści „Wytycznych w sprawie sprzedaży nieruchomości Zasobu Własności Rolnej Skarbu Państwa" stanowiących załącznik do zarządzenia nr 29/13 Prezesa ANR z dnia 5 grudnia 2013 r. w sprawie sprzedaży nieruchomości Zasobu Własności Rolnej Skarbu Państwa ${ }^{12}$ - w odniesieniu do osób fizycznych spełniających kryteria rolnika indywidualnego można mówić w ich przypadku o odrębnościach w porównaniu do innych uprzywilejowanych pierwszeństwem dzierżawców - w praktyce zbywania przez ANR gruntów dzierżawionych (co wynika z ust. 33 wytycznych). Nie można jednakowoż tracić z pola widzenia tego, że treść zarządzenia nie jest aktem powszechnie obowiązującym, a jego nierespektowanie nie ma żadnego wpływu na skuteczność umowy sprzedaży gruntu z Zasobu.

Z treści u.g.n.r. wynika, że prawodawca uznał za priorytetowy tryb przetargowy przy podstawowej formie zagospodarowania gruntów Zasobu, którą jest sprzedaż, stąd pojawia się pytanie, czy można w treści u.g.n.r. odnaleźć podstawy dla obwarowanego jakąkolwiek sankcją nakazu podjęcia przez ANR, przed skorzystaniem z innych wariantów zagospodarowania nieruchomości z ZWRSP, próby sprzedaży gruntów rolnych Zasobu na rzecz osób powiększających, czy też tworzących gospodarstwo rodzinne. Art. 24 ust. 1 pkt 1 stanowi, że w pierwszej kolejności powinno

10 Raport ANR..., op. cit., s. 6

11 Jakkolwiek nie można zapominać o tym, że w przypadku dzierżaw wielkoobszarowych ANR, na mocy art. 4 ustawy z dnia 16 września 2011 r. wypowiadała umowy dzierżawy w części dotyczącej 30\% użytków rolnych. 
się podjąć próbę sprzedaży nieruchomości ZWRSP, ale po pierwsze, nie przewidziano $\mathrm{w}$ związku z tym expressis verbis żadnej sankcji, po drugie zaś, nakazu podjęcia próby sprzedaży nie skojarzono z jakąkolwiek kategorią podmiotów (w tym zwłaszcza rolników indywidualnych). Pojawia się stąd pytanie, czy można by pokusić się o wyinterpretowanie takiego nakazu i takiej sankcji w drodze innych niż językowe metod wykładni. Wprawdzie można by usiłować wywieść prawny obowiązek podjęcia próby sprzedaży gruntu ZWRSP w pierwszej kolejności skierowanej do osób powiększających, czy też tworzących gospodarstwo rodzinne z odczytania art. 24 ust. 1 pkt $1 \mathrm{w}$ kontekście art. 6 ust. 1 pkt 1 u.g.n.r., mówiącego o tym, że Agencja realizuje zadania w zakresie tworzenia i poprawy struktury obszarowej gospodarstw rodzinnych, jednak byłoby to zadanie nadzwyczaj karkołomne. Skoro jednak na wstępie konstatujemy, że z samego odczytywanego literalnie art. 24 ust. 1 pkt 1 nie da się zrekonstruować normy obwarowanej jakąś sankcją, to tym bardziej nie będzie to wynikało ze sposobu odczytania tego przepisu bardziej dowolnego, bo przełamującego językowe jego znaczenie $\mathrm{z}$ odwołaniem jedynie do przepisu art. 6 ust. 1 pkt 1 u.g.n.r. Nie trzeba wszak tłumaczyć, że tak ogólne przepisy, jak zawarte w art. 6 ust. u.g.n.r. nie mogą być samoistnym źródłem, czy też jedynym argumentem w rekonstrukcji - przełamującej językowe rezultaty wykładni - norm z treści przepisów danego aktu prawnego, zwłaszcza jeśli chcielibyśmy wpleść tam tak radykalną sankcję, jak sankcja nieważności. Wymagałoby to dużo głębszego uzasadnienia celowościowego, którego chyba jednak brak. Nie można tracić z pola widzenia również tego, że odwołując się w ten jakże liberalny (by nie rzec - nonszalancki) sposób do treści art. 6 ust. 1 pkt 1 u.g.n.r. jako źródła dla ustalenia znaczenia innych przepisów tego aktu - zawarty w art. 24 ust. 1 pkt 1 termin „sprzedaż” rozumielibyśmy wówczas jako „sprzedaż na rzecz osób powiększających albo tworzących gospodarstwo rodzinne" zawężając jego literalne, jednoznaczne znaczenie (lege non distinguente) i do tego jeszcze - z normą o tak wyznaczonej klasie podmiotów - łączylibyśmy nigdzie nie wysłowiony wprost i nie poparty innymi argumentami rygor nieważności czynności dokonanej z jej pogwałceniem. Generalnie nie jest wyłączone skojarzenie sankcji nieważności z naruszeniem danej normy prawnej odwołując się do jej celu społeczno-gospodarczego, jednak w tym przypadku taka próba jest skazana na niepowodzenie.

Umiejscawiając przetargowy tryb sprzedaży gruntów ZWRSP na rzecz osób tworzących, czy też powiększających gospodarstwo rodzinne w ramach priorytetów Agencji trzeba wskazać, że zgodnie z ust. 29 załącznika do zarządzenia Prezesa ANR nr 29/2013 nieruchomości rolne o powierzchni przekraczającej 1 ha w pierwszej kolejności Agencja przeznacza do sprzedaży w drodze przetargu ograniczonego, którego uczestnikami mogą być osoby wskazane w art. 29 ust. 3a pkt 1 u.g.n.r. Stąd można powiedzieć, że co najmniej deklarowany przez Agencję sposób wykonywania kompetencji do gospodarowania mieniem Zasobu jest ukierunkowany 
na wspieranie gospodarki rodzinnej w rolnictwie. Praktyka stosowania ustawy jest zresztą z nim zgodna. ${ }^{13}$ Wskazać należy, że w 2013 r. ustalono w procedurach przetargowych nabywców 51 tys. ha gruntów, w tym przeszło 34 tys. w trybie ograniczonym (niemal wszystkie w przetargach ograniczonych skierowanych do osób powiększających gospodarstwa rodzinne). Symptomatyczne jest, że na przeszło 2800 przetargów ograniczonych jedynie dwa adresowane były do innych kategorii uczestników niż rolnicy indywidulani powiększający gospodarstwa rodzinne.

Art. 29 ust. 3b u.g.n.r. wskazuje na siedem kategorii podmiotów, które mogą być uczestnikami tej procedury. Zwraca uwagę to, że w większości przypadków, w których dopuszczalne jest przeprowadzenie przetargu ograniczonego mamy do czynienia z instrumentami wsparcia gospodarki rodzinnej w rolnictwie, gdyż podmioty tam wymienione bądź powiększają, bądź tworzą gospodarstwo rodzinne. Jedynie w przypadku trzech ostatnich kategorii podmiotów (a więc repatriantów, rolników, którzy zbyli wcześniej grunty gospodarstw na cele publiczne, jak i spółek, w których udziały bądź akcje w całości należą do byłych pracowników ppgr) ustawodawca nie nawiązuje do pojęcia gospodarstwa rodzinnego.

Z perspektywy praktyki ANR w zakresie zbywania gruntów Zasobu najistotniejsza jest kategoria uczestników procedur ograniczonych wskazana w pkt 1 art. 29 ust. 3b u.g.n.r. - rolnicy indywidualni powiększający gospodarstwo rodzinne. W stosunku do poprzednio obowiązującej regulacji będącej jej odpowiednikiem (przed 3 grudnia 2011 r. zawartej w art. 29 ust. 3b pkt 1 lit. mamy do czynienia z bardziej precyzyjnym uregulowaniem, pozostawiającym mniejsze pole do dowolności interpretacyjnych. Jest to również pochodną usunięcia niektórych mankamentów uprzednio obowiązującej definicji rolnika indywidulanego zawartej w u.k.u.r. ${ }^{14}$, ponieważ umieszczając w tym przepisie terminy ,,rolnik indywidualny”, jak i ,gospodarstwo rodzinne" ustawodawca odwołał się do pojęć mających ustalone normatywnie znaczenie na gruncie ustawy o kształtowaniu ustroju rolnego. I tak, uczestnikiem przetargu może być rolnik indywidualny, powiększający gospodarstwo rodzinne, zaś nabywana nieruchomość ma być położona w gminie, w której rolnik ma miejsce zamieszkania bądź w gminie graniczącej z tą gminą. Trzeba podkreślić, że z samego pojęcia ,gospodarstwo rodzinne" nie wynika, że nieruchomości wchodzące w jego skład muszą się znajdować w gminie, w której ma miejsce zamieszkania rolnik, czy też w gminach z tą gminą graniczących. Wzajemne rozmieszczenie gruntów gospodarstwa dookreśla jedynie obecne w definicji gospodarstwa rolnego (vide art. 2 pkt u.k.u.r.) kryterium zorganizowanej całości gospodarczej, co stanowi kwestię związaną z okolicznościami danego przypadku, a nie jest determinowane sztywnymi re-

13 Jakkolwiek nie można tracić z pola widzenia tego, że to pierwszeństwo w nabyciu nieruchomości nie powiązane normatywnie w żaden sposób z regulacją gospodarstwa rodzinnego dominuje w praktyce rozdysponowania mienia Zasobu, faktycznie stawiając procedury przetargowe na drugim planie. ustroju rolnego, „Studia luridica Agraria” 2012, t. X, s. 473 i n. 
gułami ustawowymi. Innymi słowy, grunty gospodarstwa mogą być rozlokowane w różnych niekoniecznie graniczących ze sobą gminach, byleby stanowić mogły funkcjonalną całość nadającą się do racjonalnej gospodarki. Zwrot mówiący o położeniu nabywanej nieruchomości w gminie graniczącej z gminą, w której mieszka uczestnik przetargu jest tożsamy z treścią art. 3 ust. 7 u.k.u.r., gdzie wyłączono prawo pierwokupu ANR, o ile nabywana na powiększenie gospodarstwa rodzinnego nieruchomość znajduje się w gminie, w której rolnik - nabywca ma miejsce zamieszkania albo w gminie graniczącej z tą gminą. Jednak ta zbieżność pojęciowa nie oznacza, że w obu przypadkach (art. 3 ust. 7 u.k.u.r. i art. 29 ust. $3 b$ pkt 1 u.g.n.r.) mamy do czynienia z realizacją tożsamego celu legislacyjnego. ${ }^{15} \mathrm{~W}$ cześniej (przed 3 grudnia 2011 r.) również w treści art. 3 ust. 7 u.k.u.r. mieliśmy do czynienia z pojęciem ,gmina sąsiednia”, nie zaś „gmina granicząca”. Sąd Najwyższy jednak uznał wówczas, odwołując się między innymi do znaczenia tego słowa w kontekście kodeksowej regulacji stosunków sąsiedzkich, że chodzi nie o wspólną granicę (a więc graniczenie ze sobą), ale o pozostawanie gruntu nabywanego i w stosunku do miejsca, w którym rolnik mieszka w takiej odległości, że rolnik może prowadzić racjonalną działalność rolniczą na nabywanym gruncie. ${ }^{16}$ Wydaję się, że - wbrew stanowisku Sądu Najwyższego - intencją ustawodawcy było wówczas użycie słowa „sąsiedni” jako synonimu dla „graniczący”, gdyż punktem odniesienia dla nabywanego gruntu zgodnie z tym przepisem było miejsce zamieszkania rolnika, co nie jest dopasowane do ujmowania relacji między nimi w kategorii zorganizowanej całości - ta pasuje raczej do wzajemnego rozmieszczenia gruntów o funkcji produkcyjnej.

Nie zmienia to faktu, że pojęcie ,gmina granicząca” wprowadzono w nowym brzmieniu art. 29 ust. $3 \mathrm{~b}$ pkt 1 oraz art. 3 ust. 7 u.k.u.r. zapewne po to, aby rozwiać wątpliwości, które w związku z przywołanym orzeczeniem Sądu Najwyższego powstawały na tle zawartego w ówczesnym art. 3 ust. 7 u.k.u.r. sformułowania o gminach sąsiednich. Obecnie nie ma już, wobec jednoznacznego znaczenia językowego słowa „graniczyć” żadnych wątpliwości w tym zakresie.

Mając na uwadze powyższe ustalenia na tle sfomułowania u.g.n.r. i u.k.u.r. zawierającego termin „graniczący”, wskazać trzeba na następujące konsekwencje na tle art. 29 ust. 3a pkt 1 u.g.n.r. Otóż w związku z taką formułą tego przepisu, nie każdy rolnik, który rzeczywiście mógłby powiększyć gospodarstwo rodzinne nabywając sprzedawany przez Agencję grunt, może przystąpić do przetargu ograniczonego. Gdyby nabywana nieruchomość rzeczywiście mogła wejść w skład jego gospodarstwa (a więc z innymi gruntami stanowić zorganizowaną całość), ale była położona w innej gminie niż ta, w której rolnik mieszka albo graniczącej z tą gminą (w gminie położonej w większej odległości), czego wszak wykluczyć nie moż-

Bo w u.k.u.r. chodzi o wyłączenie prawa pierwokupu ANR, a w u.g.n.r. o wskazanie kręgu uprawnionych do wzięcia udziału w przetargu.

Zob. wyrok Sądu Najwyższego z dnia 29 stycznia 2008 r., sygn. akt IV CSK 447/07, Lex nr 371411. 
na, to pozbawiony byłby on prawnej możliwości wzięcia udziału w takim przetargu ze względu na restryktywne ujęcie treści art. 29 ust. 3a pkt 1 u.g.n.r. Jednak nie należy z tego tylko powodu oceniać owego rozwiązania negatywnie. Obecnie obowiązująca regulacja wprowadza proste, łatwo weryfikowalne kryterium pozwalające na ocenę, czy dany podmiot spełnia przesłanki udziału w przetargu. Wystarczy zweryfikować położenie nieruchomości na terenie konkretnej gminy. ${ }^{17}$ Gdyby organizator musiał oceniać każdorazowo, czy grunty wystawiane na przetarg mogą stanowić zorganizowaną całość z gruntami gospodarstwa zainteresowanego wzięciem udziału przetargu rolnika, bez wprowadzenia jakiegoś upraszczającego tę ocenę kryterium, byłoby to rozwiązaniem nieoperatywnym (wymagałoby ze strony osób zaangażowanych w prowadzenie procedury przetargowej posiadania wiadomości specjalnych z zakresu rolnictwa).

W przypadku kategorii podmiotów wskazanych w pkt 2 artykułu 29 ust. 3b ustawodawca wprowadza expressis verbis jedną przesłankę warunkującą udział w przetargu ograniczonym - są to kwalifikacje rolnicze. Należy je weryfikować według treści u.k.u.r. - zgodnie z wyraźnym odesłaniem zawartym w treści tego przepisu u.g.n.r. Z uwagi jednak na to, że osoba taka ma utworzyć gospodarstwo rodzinne co oznacza, że nabywca ma w jakiejś perspektywie czasu zyskać przymiot rolnika indywidulanego, pojawia się następujące pytanie. Otóż, czy taki uczestnik przetargu nie powinien jednak spełnić przynajmniej niektórych nie wymienionych wprost w art. 29 ust. 3b pkt 2 u.g.n.r. warunków budujących zgodnie z treścią art. 6 ust. 1 u.k.u.r. pojęcie ,,rolnik indywidualny” - choćby w odniesieniu do miejsca zamieszkania na terenie gminy, w której umiejscowiona jest sprzedawana nieruchomość? Wątpliwości te może uzasadniać również treść art. 29 ust. 3b pkt 1, gdzie pojawia się kryterium miejsca zamieszkania rolnika. Uważam jednak, że brak jest podstaw do stawiania wymogu dotyczącego zamieszkania na terenie gminy, w której położona jest zbywana przez ANR nieruchomość uczestnikowi przetargu, o którym mowa w art. 29 ust. 3b pkt 2. Po pierwsze, treść tego przepisu nie przewiduje wyraźnie takiego wymogu. Po drugie, miejsce zamieszkania w ramach definicji „rolnik indywidualny” (a więc już prowadzący gospodarstwo rodzinne) zawartej w u.k.u.r. nie pełni roli, która byłaby istotna z perspektywy podmiotu dopiero tworzącego takie gospodarstwo. Otóż trzeba zdawać sobie sprawę, że osoba nabywająca nieruchomość celem utworzenia gospodarstwa rodzinnego nie stanie się automatycznie rolnikiem indywidualnym, gdyż w modelowej sytuacji powinna po nabyciu gruntu, prowadzić działalność rolniczą w nowo utworzonym gospodarstwie rolnym (jeszcze nie rodzinnym) co najmniej przez 5 lat i mieszkać w gminie, w której pogruntami wchodzącymi w jego skład zorganizowaną całość - jest to kryterium esencjalne gospodarstwa rolnego, ale $w$ typowej sytuacji położenie $w$ gminie określonej zgodnie z treścią art. 29 ust. 3b pkt 1 u.g.n.r. implikuje wypełnienie warunku tworzenia zorganizowanej całości gospodarczej z gruntami będącymi własnością uczestnika przetargu. 
łożona jest jedna z nieruchomości wchodzących w jego skład. Stąd widać, że nabycie gruntu to dopiero pierwszy krok prowadzący do powstania gospodarstwa rodzinnego, zaś kryterium zamieszkania w kontekście pojęcia „,rolnik indywidualny” jest istotne w dłuższej (5-letniej) perspektywie czasowej, nie wywołuje zaś od razu żadnych skutków w związku z samym nabyciem gruntu z Zasobu. Nie ma wobec tego podstaw również i do tego, aby wprowadzać obowiązek zamieszkania przez uczestnika przetargu w gminie, w której położona jest sprzedawana nieruchomość również w drodze wykładni celowościowej.

Inną kwestią jest natomiast to, że w treści u.g.n.r. nie zawarto żadnych regulacji mających zapewnić, że nabyta celem powiększenia, czy też utworzenia gospodarstwa rodzinnego nieruchomość faktycznie będzie wykorzystywania przez nabywcę do prowadzenia działalności rolniczej wykonywanej osobiście, ani też że gospodarstwo, w skład którego wchodzi ta nieruchomość utrzyma status gospodarstwa rodzinnego (choćby przez powstrzymanie się przez prowadzącego go rolnika indywidualnego od jego powiększenia ponad 300-hektarową normę maksymalną). Na marginesie zauważyć wypada, że zgodnie z treścią $§ 2$ pkt 1 rozporządzenia Ministra Rolnictwa i Rozwoju Wsi z dnia 16 lutego 2012 r. w sprawie szczegółowych warunków rozkładania na raty należności z tytułu sprzedaży nieruchomości z Zasobu Własności Rolnej Skarbu Państwa oraz wysokości oprocentowania rozłożonej na raty należności ${ }^{18}$ prawodawca przewidział, że rozłożenie należności Agencji na raty może dotyczyć w szczególności nabywcy, który tworzy albo powiększa gospodarstwo rodzinne, o ile zobowiąże się do utrzymywania nabywanej nieruchomości rolnej zgodnie z zasadami prawidłowej gospodarki w celu wykonywania na niej działalności rolniczej. Jednak nie jest to regulacja specyficzna dla umów zawieranych w każdym przypadku w trybie przetargu ograniczonego. W praktyce Agencja wprowadza do treści umów zawieranych ze zwycięskimi uczestnikami przetargów ograniczonych klauzule, mające zapewnić wykorzystanie przez nabywców nieruchomości $\mathrm{w}$ celu prowadzenia tam działalności rolniczej. Otóż, zgodnie z treścią załącznika do wytycznych zawierającego proponowaną treść klauzul w umowach zawieranych przez ANR (zarządzenie Prezesa ANR nr 29/13), przewiduje się ustanowienie w umowie sprzedaży gruntu w celu powiększenia bądź utworzenia gospodarstwa rodzinnego na rzecz ANR prawa odkupu między innymi w przypadku, gdy nieruchomość będzie wykorzystywana na inny cel niż prowadzenie działalności rolniczej, jak też gdy prowadzona działalność rolnicza nie jest wykonywana na nabywanej nieruchomości osobiście przez nabywcę. Dodatkowo nabywca zobowiązać się musi do prowadzenia osobiście działalności rolniczej na nabywanym gruncie w okresie 10 lat od zawarcia umowy, nieustanawiania w tym okresie hipoteki na nabywanym gruncie, informowania Agencji o zamiarze zbycia nieruchomości. Niedotrzymanie tych warunków w okresie 10 lat od zawarcia umowy z Agencją powo- 
dować będzie powstanie po stronie nabywcy obowiązku zapłaty na rzecz Agencji kwoty równej wysokości $40 \%$ ceny nabycia. Są to, co oczywiste, bardzo restryktywne warunki, wiążące nabywcę w relatywnie długim okresie. W tej materii wypowiedziała się również Najwyższa Izba Kontroli, uznając, że owe zapisy umowne budzą wątpliwości, gdyż mogą stanowić ,nieproporcjonalną ingerencję w konstytucyjną zasadę ochrony własności", ${ }^{19} \mathrm{w}$ związku z tym nie powinny być stosowane, gdyż nie wynikają z ustawy. Zdaniem NIK ,art. 64 ust. 3 Konstytucji RP stanowi, że własność może być ograniczona tylko w drodze ustawy i tylko w zakresie, w jakim nie narusza ona istoty prawa własności”. ${ }^{20}$ Wydaje się, że obiekcje NIK są w tej mierze uzasadnione. Jakkolwiek niedopuszczalności zamieszczania owych klauzul w treści umów zawieranych z kontrahentami Agencji upatrywałbym raczej w konstrukcji normatywnej kompetencji ANR do dysponowania mieniem ZWRSP nie sięgając w pierwszym rzędzie do przepisów Konstytucji. Mianowicie, na co wskazuje się w doktrynie, ANR jest w odniesieniu do mienia Zasobu - wyposażona jedynie w szczegółowe kompetencje do dokonywania względem nich czynności wskazanych enumeratywnie przez prawodawcę, w szczególności w treści art. 24 ust. 1 u.g.n.r. ${ }^{21}$ Nie jest ona zaś w odniesieniu do mienia Zasobu podmiotem, który wykonywałby pełną gamę uprawnień właścicielskich za Skarb Państwa. Zgodnie z treścią art. 24 ust. 1 pkt 1 u.g.n.r. Agencja może sprzedawać mienie Zasobu, jednakże nie oznacza to, moim zdaniem, pełnej dowolności w konstruowaniu poszczególnych zapisów tych umów. Postanowienia umów powinny być ściśle powiązane z celami, które mają realizować poszczególne formy zagospodarowania mienia Zasobu, chyba że szczególne przepisy wyraźnie pozwalają na uzupełnienie treści umowy o inne postanowienia. Innymi słowy, umowa sprzedaży ma służyć przede wszystkim przeniesieniu własności na nabywcę za uzgodnioną cenę, zaś inne jej zapisy nie powiązane funkcjonalnie $\mathrm{z}$ tymi skutkami powinny znajdować uzasadnienie $\mathrm{w}$ poszczególnych, merytorycznych przepisach u.g.n.r. Nie wystarczy tu powołanie się jedynie na ogólnie sformułowane zadania Agencji wymienione w art. 6 u.g.n.r. - moim zdaniem nie mogą być źródłem dla rozszerzenia zakresu kompetencji szczegółowych w zakresie gospodarowania mieniem Zasobu na tyle szeroko, aby obejmowały również możliwość stosowania przywołanych powyżej klauzul umownych.

Z tego, co wynika z wcześniej prowadzonych rozważań, na ANR nie spoczywa obwarowany sankcją nieważności obowiązek organizowania przetargów ograniczonych na sprzedaż gruntów ZWRSP adresowanych do osób tworzących bądź powiększających gospodarstwa rodzinne. Nie wynika z tego oczywiście, że niezachowanie

„Informacja o wynikach kontroli Sprzedaż nieruchomości rolnych Zasobu Własności Rolnej Skarbu Państwa przez oddziały terenowe Agencji Nieruchomości Rolnych w Szczecinie, w Warszawie i we Wrocławiu”, Najwyższa Izba Kontroli, s. 9, www.nik.gov.pl Ibidem.

21 Por. Z. Truszkiewicz, Powierzenie gospodarowania gruntami Skarbu Państwa - zagadnienia konstrukcyjnoprawne, [w:] Z zagadnienień prawa rolnego, cywilnego i samorządu terytorialnego, Białystok 2012, s. 318 i n. zwłaszcza s. 321. 
wymogów dotyczących warunków przeprowadzenia tych przetargów (w razie podjęcia przez ANR próby sprzedaży nieruchomości w drodze przetargu ograniczonego) takiej sankcji nie pociąga. W doktrynie i orzecznictwie za raczej niekontrowersyjny należy uznać pogląd, że uchybienie wymogom towarzyszącym przetargom obligatoryjnym może powodować nieważność umowy zawartej w wyniku wadliwie przeprowadzonej procedury. Nie chodzi jednak o jakiekolwiek naruszenie przepisów dotyczących przetargów obligatoryjnych, ale o takie naruszenie, które miało zwłaszcza wpływ na wynik przetargu. ${ }^{22}$ Jest to istotne, mając na uwadze przedmiot dotychczasowych rozważań, przy ocenie skutków dopuszczenia do udziału w przetargu ograniczonym osoby, która nie spełnia kryteriów wskazanych w treści art. 29 ust. 3b u.g.n.r., przykładowo gdy nieruchomość wystawiona do przetargu nie leży w gminie, w której zainteresowany jej nabyciem mieszaka, ani w gminie graniczącej z tą gminą.

Pochopne byłoby przyjęcie, że samo zakwalifikowanie do uczestnictwa takiej osoby powodowałoby nieważność umowy zawartej w drodze takiej procedury. Skutkiem tego musiałoby być wypaczenie wyniku przetargu. W przetargu ustnym wystarczyłoby, moim zdaniem, gdyby taki uczestnik zgłaszał postąpienia akceptowane przez organizatora, nawet gdyby licytacji ostatecznie nie wygrał. Mielibyśmy jednak bezpośredni wpływ podejmowanych przez niego czynności (składanych ofert) na rezultat konkurencyjnej rywalizacji pozostałych uczestników. Inaczej należałoby ocenić dopuszczenie oferty złożonej przez taką osobę do przetargu pisemnego. Zasadniczo, jeśli nie zostałaby wybrana jako najkorzystniejsza, nie miałaby wpływu na wynik przetargu, stąd nawet gdyby misja przetargowa dokonała jej merytorycznej oceny, ale wybranoby w dalszej kolejności ofertę złożoną przez innego uczestnika, nie mielibyśmy do czynienia z wpływem tej oferty na ostateczny wynik postępowania.

Podsumowując, sam fakt wprowadzenia do u.g.n.r. regulacji przetargu ograniczonego do kategorii osób powiększających bądź tworzących gospodarstwo rodzinne zasługuje na pozytywną ocenę. Należy również dostrzec to, że większa część gruntów obecnie rozdysponowywanych z wykorzystaniem procedur przetargowych jest sprzedawana właśnie w trybie przetargu ograniczonego skierowanego do osób powiększających gospodarstwa rodzinne. Jednak nie można tracić z pola widzenia

Por. też § 15 rozporządzenia Ministra Rolnictwa i Rozwoju Wsi z dnia 30 kwietnia 2012 r. w sprawie szczegółowego trybu sprzedaży nieruchomości Zasobu Własności Rolnej Skarbu Państwa i ich części składowych, warunków obniżenia ceny sprzedaży nieruchomości wpisanej do rejestru zabytków oraz stawek szacunkowych gruntów (Dz.U. z 2012 r., poz. 540). Nie wdając się w szczegółowe rozważania dotyczące treści tego przepisu wskazuję jednak, że wbrew dosłownemu brzmieniu nie chodzi w nim zasadniczo o czynność konstytutywna unieważnienia, ale o deklaratywne stwierdzenie wadliwości czynności przetargowych, co skutkowałoby nieważnością zawartej w drodze przetargu umowy (zob. podjętą na tle przepisów wykonawczych do ustawy z dnia 21 sierpnia 1997 r. o gospodarce nieruchomościami uchwałę Sądu Najwyższego z dnia 13 lutego 2003 r., sygn. akt III CZP 95/02, OSNC 2003, nr 11, poz. 146 oraz wyrok Sądu Najwyższego z dnia 30 stycznia 2009 r., sygn. akt II CSK 437/08, Lex nr 599752). 
tego, że i tak zdecydowania większość gruntów jest zbywana w drodze bezprzetargowej z wykorzystaniem instytucji pierwszeństwa, co jest efektem realizowanej polityki rozdysponowania gruntów z Zasobu w minionych latach, kiedy wśród stosowanych form rozdysponowania dominowała dzierżawa. Widoczny jest jednak zupełny brak rozwiązań prawnych mających zapewnić rzeczywiste prowadzenie działalności rolniczej na nabytych przez rolników indywidualnych gruntach z Zasobu. Próby zastąpienia tych braków normatywnych w praktyce działania Agencji poprzez wprowadzenie omawianych powyżej zapisów do umów zawieranych z nabywcami nieruchomości Zasobu budzi zaś wątpliwości co do ich dopuszczalności, mając na uwadze wyznaczony w u.g.n.r. zakres kompetencji ANR w gospodarowaniu mieniem ZWRSP. 


\section{RESTRICTED TENDERING PROCESS IN THE SALE OF LAND FROM THE AGRICULTURAL PROPERTY STOCK OF THE STATE TREASURY AS AN INSTRUMENT TO SUPPORT FAMILY FARMS (SELECTED ISSUES)}

Keywords: tender procedure, Agricultural Property Stock of the State Treasury, family farm

One of the main directions of activities conducted by the Agricultural Property Agency is to support agricultural farms. The most significant manifestation of such activities, aimed at supporting this objective, is the sale of land from the Agricultural Property Stock of the State Treasury to individual farmers who wish to enlarge their family farms, under a restricted tender procedure. Although the Act on the Management of the Agricultural Property Stock of the State Treasury also provides for other categories of entities - i.e. other potential participants of such restricted tenders, the procedures aimed at individual farmers are of the greatest importance in the Agency's activities in this field. However, it should be noted that the statutory regulation concerning tenders for the sale of land with a view to supporting family farms is not complete and does not provide for any legal instruments designed not only to ensure that the land will be acquired by persons with adequate qualifications, but also that such land will be used by the purchaser for the conduct of agricultural activity. Therefore, the Agency introduces appropriate clauses into agreements with such purchasers in order to ensure that agricultural activity is conducted on the land acquired by them. However, the acceptability of such clauses may raise reasonable doubts. 